Thomas Hardy's Legal Fictions 
Edinburgh Critical Studies in Victorian Culture

Series Editor: Julian Wolfreys

Volumes available in the series:

In Lady Audley's Shadow: Mary Elizabeth Braddon and Victorian Literary Genres

Saverio Tomaiuolo

9780748641154 Hbk

Blasted Literature: Victorian Political

Fiction and the Shock of Modernism

Deaglán Ó Donghaile

$9780748640676 \mathrm{Hbk}$

William Morris and the Idea of

Community: Romance, History and

Propaganda, 1880-1914

Anna Vaninskaya

9780748641499 Hbk

Walter Pater: Individualism and Aesthetic

Philosophy

Kate Hext

$9780748646258 \mathrm{Hbk}$

London's Underground Spaces:

Representing the Victorian City, 1840-1915

Hwang Haewon

$9780748676071 \mathrm{Hbk}$

Moving Images: Nineteenth-Century

Reading and Screen Practices

Helen Groth

$9780748669486 \mathrm{Hbk}$

1895: Drama, Disaster and Disgrace in

Late Victorian Britain

Nicholas Freeman

$9780748640560 \mathrm{Hbk}$

Determined Spirits: Eugenics, Heredity

and Racial Regeneration in Anglo-

American Spiritualist Writing, 1848-1930

Christine Ferguson

$9780748639656 \mathrm{Hbk}$

Jane Morris: The Burden of History

Wendy Parkins

9780748641277 Hbk

Thomas Hardy's Legal Fictions

Trish Ferguson

9780748673247 Hbk

Dickens's London: Perception,

Subjectivity and Phenomenal Urban

Multiplicity

Julian Wolfreys

9780748640409 Hbk

Re-Imagining the 'Dark Continent' in fin de siècle Literature

Robbie McLaughlan

$9780748647156 \mathrm{Hbk}$

Roomscape: Women Readers in the

British Museum from George Eliot to

Virginia Woolf

Susan David Bernstein

$9780748640652 \mathrm{Hbk}$

Forthcoming volumes:

Her Father's Name: Gender, Theatricality and Spiritualism in Florence Marryat's

Fiction

Tatiana Kontou

$9780748640072 \mathrm{Hbk}$

British India and Victorian Culture

Máire ni Fhlathúin

$9780748640683 \mathrm{Hbk}$

Women and the Railway, 1850-1915

Anna Despotopoulou

$9780748676941 \mathrm{Hbk}$

Visit the Edinburgh Critical Studies in Victorian Culture web page at www.

euppublishing.com/series/ecve

Also Available:

Victoriographies - A Journal of Nineteenth-Century Writing, 1790-1914, edited by Julian Wolfreys

ISSN: 2044-2416

www.eupjournals.com/vic 


\title{
Thomas Hardy's Legal Fictions
}

\author{
Trish Ferguson
}


(C) Trish Ferguson, 2013

Edinburgh University Press Ltd

22 George Square, Edinburgh EH8 9LF

www.euppublishing.com

Typeset in $10.5 / 13$ Sabon by Servis Filmsetting Ltd, Stockport, Cheshire, printed and bound in Great Britain by CPI Group (UK) Ltd, Croydon CR0 4YY

A CIP record for this book is available from the British Library

ISBN 9780748673247 (hardback)

ISBN 9780748673254 (webready PDF)

ISBN 9780748673261 (epub)

The right of Trish Ferguson

to be identified as author of this work

has been asserted in accordance with

the Copyright, Designs and Patents Act 1988. 